\title{
AGE OF THE RIBEIRÃO DA FOLHA OPHIOLITE, ARAÇUAÍ OROGEN: THE U-Pb ZIRCON (LA-ICPMS) DATING OF A PLAGIOGRANITE
}

\author{
Gláucia Nascimento Queiroga ${ }^{1}$, Antônio Carlos Pedrosa-Soares ${ }^{1}$, Carlos Maurício Noce ${ }^{1}$, \\ Fernando Flecha de Alkmim², Márcio Martins Pimentel ${ }^{3}$, Elton Dantas ${ }^{3}$, Maximiliano \\ Martins $^{1}$, Cristiane Castañeda ${ }^{1}$, Marcos Tadeu de Freitas Suita ${ }^{2}$, Hazel Prichard ${ }^{4}$
}

\section{RESUMO}

\begin{abstract}
O Orógeno Araçuaí, de idade neoproterozóica, se estende da margem sudeste do Cráton do São Francisco ao Oceano Atlântico, entre os paralelos $15^{\circ}$ e $21^{\circ} \mathrm{S}$. O estágio rifte da bacia precursora do Orógeno Araçuaí é balizado pela idade U-Pb SHRIMP de ca. 875 Ma dada por granitos anorogênicos. A evolução orogênica é subdividida nos estágios pré-colisional (ca. 630-585 Ma), sin-colisional (ca. 585-560 Ma), tardi-colisional (ca. 560-530 Ma) e pós-colisional (ca. 530-490 Ma). Remanescentes de rochas magmáticas de assoalho oceânico, localizados no setor central deste orógeno, têm sido descritos na literatura geológica desde 1990. O mais completo destes registros oceânicos é o ofiolito de Ribeirão da Folha, situado nos arredores da vila homônima, no município de Minas Novas, MG. O ofiolito de Ribeirão da Folha é uma associação litológica tectonicamente desmembrada, composta por fatias de rochas meta-ultramáficas e metamáficas que foram embutidas por empurrões em pacotes da Formação Ribeirão da Folha (unidade distal do Grupo Macaúbas). Esta formação, na área enfocada, consiste de micaxistos e cianita-grafita xistos (pelitos pelágicos), com intercalações de metacherts sulfetados, diopsiditos sulfetados, corpos de sulfetos maciços, formações ferríferas bandadas dos tipos óxido, sulfeto e silicato, e orto-anfibolitos finos (metabasaltos), metamorfisados nas zonas da cianita da fácies anfibolito médio. Dados geotermobarométricos dos micaxistos peraluminosos revelaram condições metamórficas em torno de $550^{\circ} \mathrm{C}$ a $5,5 \mathrm{kbar}$. As assinaturas litoquímicas das rochas metamáficas e meta-ultramáficas revelam afinidade ofiolítica e origem em assoalho oceânico. Os dados isotópicos $\mathrm{Sm}-\mathrm{Nd}$ destas rochas mostram valores positivos de epsilon $\mathrm{Nd}(+3 \mathrm{a}+7)$, e as idades modelo e isocrônica sugerem desenvolvimento de litosfera oceânica durante o Neoproterozóico. Todas as tentativas anteriores de recuperação de zircão a partir de volumosas amostras das rochas metamáficas foram infrutíferas. Contudo, corpos leucocráticos semelhantes a plagiogranito foram reconhecidos poucos anos atrás e se tornaram um dos principais alvos da tese de doutorado da primeira autora. Estes corpos ocorrem sob a forma de veios irregulares com dimensões milimétricas a centimétricas (até $50 \mathrm{~cm}$ ), e são encaixados por orto-anfibolito bandado de granulação média a grossa (metadolerito a metagabro). Os corpos leucocráticos consistem de metaplagiogranito foliado, composto essencialmente por plagioclásio cálcico com bordas albíticas, quartzo, hornblenda e epidoto, com titanita, sulfeto, apatita e zircão como os principais minerais acessórios. Os cristais de zircão da amostra de plagiogranito são euédricos e muito límpidos, e mostram morfologia prismática elongada (3:1), sugerindo origem magmática. Análises U-Pb por LA-ICPMS (Laser Ablation Inductively Coupled Mass Spectrometry) foram realizadas em dezoito cristais de zircão e mostram resultados concordantes, indicando idade de cristalização magmática de $660 \pm 29 \mathrm{Ma}$. Esta idade baliza a época de geração de crosta oceânica na bacia precursora do Orógeno Araçuaí. O espalhamento de algumas das análises ao longo da curva concórdia sugere perda de $\mathrm{Pb}$ devido ao metamorfismo de fácies anfibolito em ca. $580 \mathrm{Ma}$. A idade de ca. $660 \mathrm{Ma}$ plagiogranito precede a maior idade U-Pb (ca. $630 \mathrm{Ma}$ ) de tonalitos deformados do arco magmático pré-colisional, bem como a idade U-Pb (ca. $582 \mathrm{Ma}$ ) dos granitos sincolisionais mais antigos.
\end{abstract}

Keywords: plagiogranite, oceanic crust, ophiolite, Ribeirão da Folha, Araçuaí Orogen

\section{INTRODUCTION}

The Neoproterozoic Araçuaí Orogen extends from the eastern margin of the São Francisco Craton to the Atlantic Ocean, between the $15^{\circ}$ and $21^{\circ} \mathrm{S}$ parallels, in southeastern Brazil (Pedrosa-Soares et al. 2001, 2007, 2008). This paper focuses on the Ribeirão da Folha area (Minas Novas region, Minas Gerais State), located in the western-central sector of the Araçuaí Orogen (Fig. 1).

The discovery of Neoproterozoic oceanic remnants in the Ribeirão da Folha area was published in the international literature by the beginning of the $1990^{\text {th }}$ decade (Pedrosa-Soares et al. 1992). Since then several 
studies have been carried out on metamagmatic and metasedimentary rocks from this and other ophiolite slivers of the Araçuaí Orogen (e.g., Pedrosa-Soares et al. 1998, 2001, Aracema et al. 2000, Suita et al. 2004, Queiroga et al. 2006). Although a Neoproterozoic age was suggested by $\mathrm{Sm}-\mathrm{Nd}$ isotopic analysis on metamafic and meta-ultramafic rocks, all attempts to recover zircon crystals from large amounts of metamafic rock samples have been unsuccessful. However, leucocratic bodies resembling plagiogranite were recognized a few years ago (Suita et al. 2004) and became one of the main study targets of the first author's doctorate thesis.

This paper presents a preliminary characterization of the plagiogranite bodies, and summarizes the $\mathrm{U}-\mathrm{Pb}$ dating carried out by using Laser Ablation Inductively Coupled Plasma Mass Spectrometry (LA-ICPMS) on zircon crystals recovered from them.

\section{GEOLOGICAL SETTING}

The geotectonic setting, stratigraphy and tectonic evolution of the Araçuaí Orogen are synthesized in Pedrosa-Soares et al. $(2001,2007,2008)$ and Alkmim et al. (2006, 2007). This orogen shows lithological records of all evolutionary stages, from the precursor basin to the post-collisional plutonism. The early rift stage of the precursor basin is constrained by the $c a$. 906 Ma mafic dykes and $875 \mathrm{Ma}$ anorogenic granites. $\mathrm{U}-\mathrm{Pb}$ dates of detrital zircon grains suggest a maximum sedimentation age of $c a .900 \mathrm{Ma}$ for the continental rift-related units of the Macaúbas Group, and of $c a$. $864 \mathrm{Ma}$ for sand-pelite deposits of the proximal passive margin. Distal passive margin and oceanic successions are represented by the Ribeirão da Folha Formation (distal unit of the Macaúbas Group) that mainly consists of sand-pelite turbidites, pelagic pelites and chemicalexhalative sediments. Metamafic and meta-ultramafic rocks of ophiolite affinity record the generation of oceanic lithosphere in the distal sector of the precursor basin. The orogenic evolution has been subdivided into the pre-collisional ( $c a$. 630-585 Ma; formation of a calc-alkaline magmatic arc and related basins), syn-collisional ( $c a$. 582-560 Ma; regional deformation and metamorphism, and generation of a huge amount of S-type granites), late collisional (ca. 560-530 Ma; S-type granites) and post-collisional (ca. 530-490 Ma; gravitational collapse of the orogen, and latest S-type and I-type plutonisms) stages.

\section{THE RIBEIRÃO DA FOLHA OPHIOLITE}

In spite of the intense tropical weathering and thick soil covers, metamafic and meta-ultramafic rocks, as well as sulfide-rich rocks can be clearly recognized in the Ribeirão da Folha area (Fig. 1). This ophiolite is a tectonic dismembered rock-assemblage composed of slices of meta-magmatic rocks thrust onto packages of the Ribeirão da Folha Formation. The main structures are shear zones and complex folding related to the regional foliation of the Araçuaí Orogen.

The thickest ophiolite slice, named Córrego do Rubinho ultramafic body (Fig. 1), is mainly composed of tremolite schists and carbonate-tremoliteanthophyllite schists (Pedrosa-Soares et al. 1992). Some metamafic rocks are massive coarse-grained orthoamphibolites interpreted as metamorphosed gabbros. They are associated with medium-grained banded ortho-amphibolites, with fine-grained borders, that resemble metamorphosed dolerite (and could represent strongly deformed sheeted dikes). The geochemical signatures of the metamafic and meta-ultramafic rocks indicate ophiolite affinity and ocean-floor origin. Sm$\mathrm{Nd}$ isotopic data from both the metamafic and metaultramafic rocks yielded positive epsilon $\mathrm{Nd}$ values $(+3$ to +7$)$. Their Sm-Nd whole-rock isochrons, as well as Sm-Nd $\mathrm{T}_{\mathrm{DM}}$ model ages, suggested development of oceanic lithosphere in Neoproterozoic times (PedrosaSoares et al. 1992, 1998, 2001).

The Ribeirão da Folha Formation consists of micaschists and kyanite-graphite schists (pelagic pelites), with intercalations of sulfide-bearing metacherts and diopisidites, massive sulfide bodies, banded iron formations (oxide, silicate and sulfide types), and rare fine-grained ortho-amphibolites (basalts), metamorphosed in the kyanite zone of the intermediate pressure amphibolite facies (Fig. 1). Geothermobarometric data indicate metamorphic PT conditions around $550^{\circ} \mathrm{C}$ and 5,5 kbar (Pedrosa-Soares et al. 1992, 1998, Queiroga et al. 2006).

\section{THE PLAGIOGRANITE AND U-Pb AGE}

Leucocratic bodies resembling plagiogranite were recognized a few years ago (Suita et al. 2004). These leucocratic bodies show irregular vein-like shapes, ranging in size from millimeters to $50 \mathrm{~cm}$, and are hosted by medium- to coarse-grained orthoamphibolites (Fig. 2).

The leucocratic veins consist of foliated metaplagiogranite composed of plagioclase, quartz, amphibole and epidote, with titanite, chlorite, sulfide, apatite and zircon as the main accessory minerals. The plagioclase is generally anorthite $\left(\mathrm{An}_{90-95}\right)$ with albitic rims and its alteration produced very significant amounts of epidote. The amphibole is hornblende with tremolite cores. It can be partially altered to Mg-chlorite. Modal proportions of felsic minerals suggest quartz diorite to diorite composition, in agreement with modern and old plagiogranites (e.g., Coleman \& Peterman 1975, Aldiss 1981, Mukasa \& Ludden 1987).

The zircon crystals recovered from a plagiogranite sample are euhedral and very clean, and show elongated prismatic (3:1) morphology, suggesting magmatic origin. $\mathrm{U}-\mathrm{Pb}$ analyses using Laser Ablation Inductively Coupled Plasma Mass Spectrometry (LA-ICPMS) were carried out on eighteen zircon crystals which yielded concordant results, indicating a crystallization age of $660 \pm 29 \mathrm{Ma}$ (Fig. 3). This age constrains the timing 
of oceanic crust generation in the precursor basin of the Araçuaí Orogen. The spread of analyses along the concordia curve suggests $\mathrm{Pb}$ loss due to the amphibolite facies metamorphism at ca. $580 \mathrm{Ma}$.

The ca. 660 Ma plagiogranite predates the oldest U$\mathrm{Pb}$ ages (ca. $630 \mathrm{Ma}$ ) of tonalites of the pre-collisional magmatic arc of the Araçuaí Orogen, as well as the U-Pb age (ca. $582 \mathrm{Ma}$ ) of the oldest syn-collisional granites (cf. Pedrosa-Soares et al. 2007, 2008).

\section{ACKNOWLEDGEMENTS}

To CNPq, CT-Infra, FINEP and FAPEMIG for financial support.

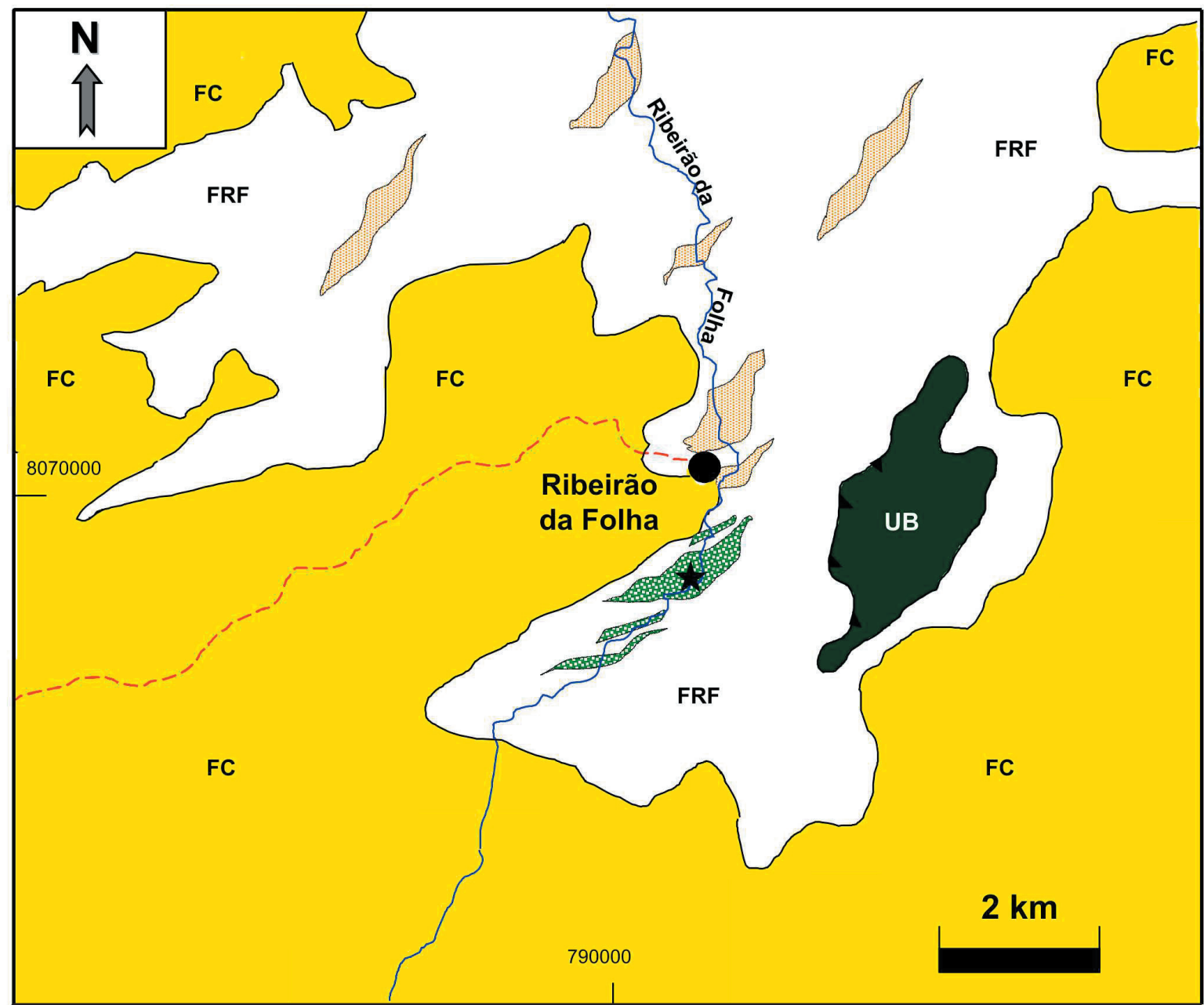

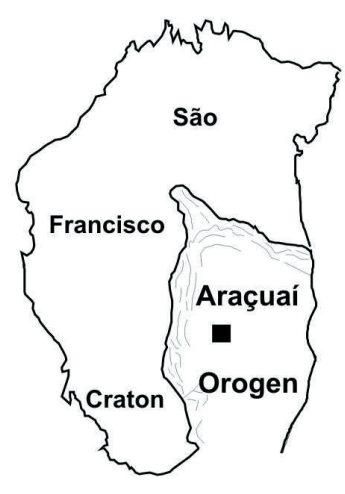

- Ribeirão da Folha area
Formação Capelinha (FC): quartzite, detrital iron formation, micaschist, graphite schist

\section{Ribeirão da Folha Formation (FRF)}

Micaschists, kyanite-graphite schists, metacherts, banded iron formations, diopsidite,

Sulfide-rich units with metacherts, massive sulfide, diopsidite, iron formations and other rocks fine-grained ortho-amphibolites

Coarse to medium-grained, massive and banded ortho-amphibolites (gabbro to dolerite)

Plagiogranite veins Meta-ultramafic body (Córrego do Rubinho)

Village - Road

Figure 1. Sketch geological map of the Ribeirão da Folha area (modified from Pedrosa-Soares et al. 1992 and Queiroga et al. 2006). 

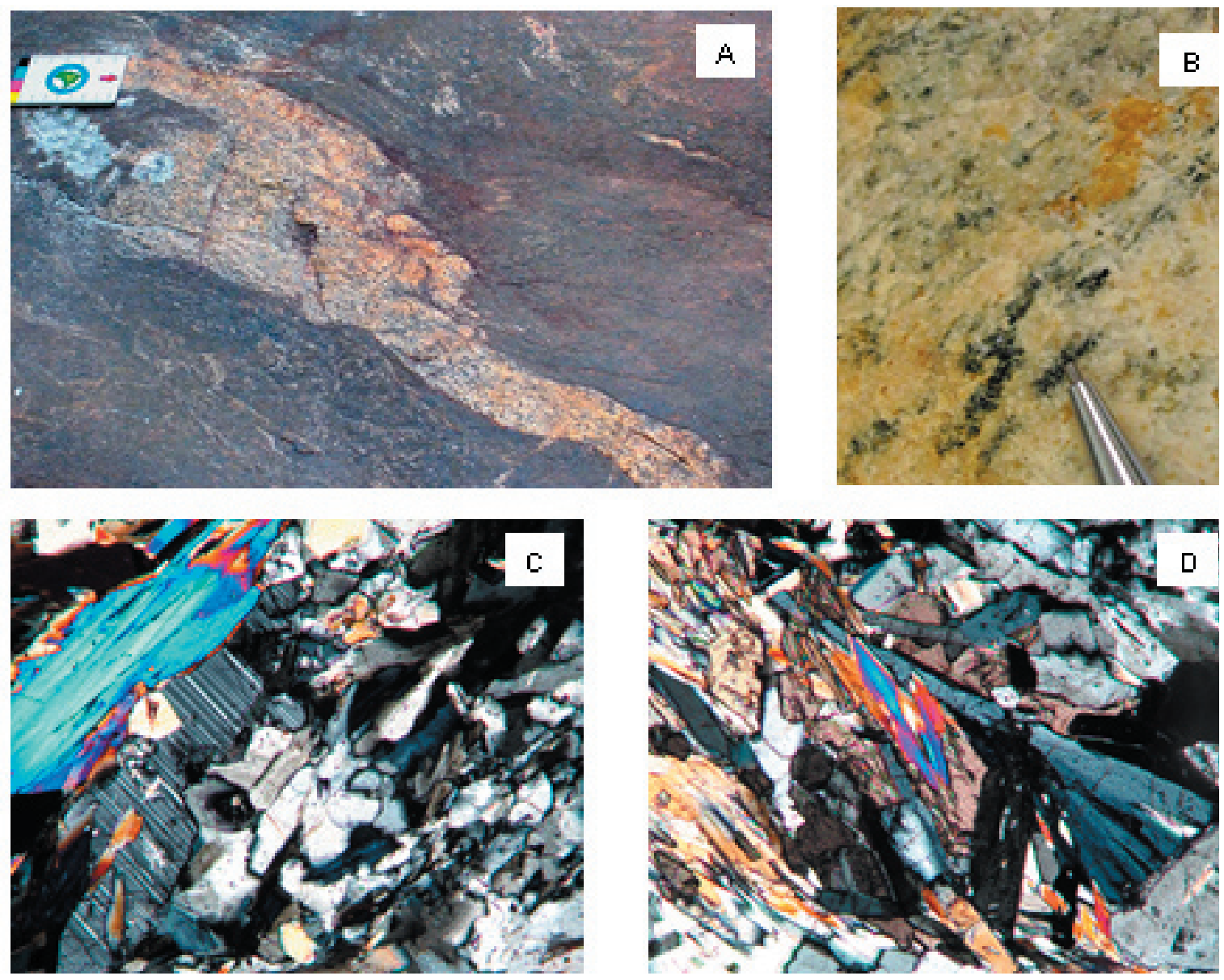

Figure 2. One of the biggest meta-plagiogranite veins ( $50 \mathrm{~cm}$ long) found in the Ribeirão da Folha area is shown in photo $A$. The regional foliation is marked by oriented amphibole crystals and light minerals in the meta-plagiogranite vein (photo B). Photomicrographies $C$ and D show mineralogical assemblages (plagioclase, amphibole, quartz, epidote, titanite) and textures of the meta-plagiogranites.

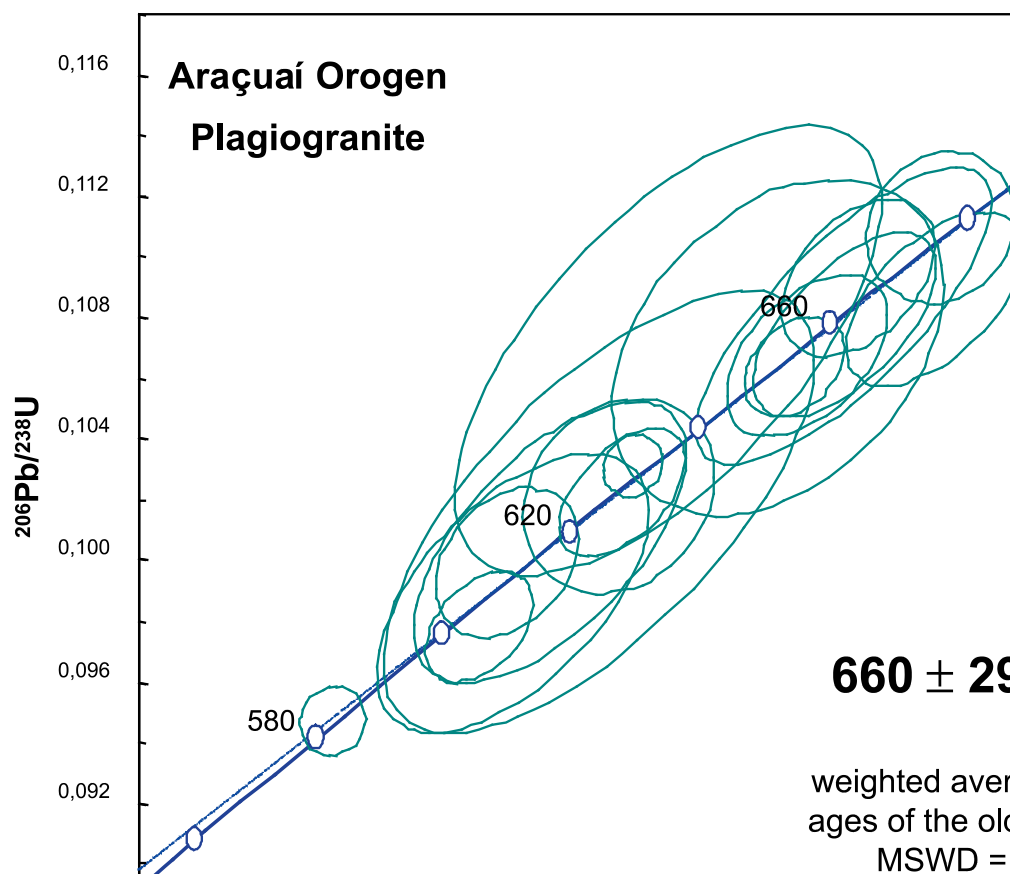

Figure 3. Concordia diagram for the U-Pb (LA-ICPMS) data from zircons of the Ribeirão da Folha plagiogranite. Analysis performed by Laboratório de Geocronologia da Universidade de Brasília. 


\section{REFERENCES}

Aldiss, D.T. 1981. Plagiogranites from the ocean crust and ophiolites. Nature, 289: 577-578.

Alkmim, F.F., Marshak, S., Pedrosa-Soares, A.C., Peres, G.G., Cruz, S.C.P. \& Whittington, A. 2006. Kinematic evolution of the Araçuaí-West Congo orogen in Brazil and Africa: Nutcracker tectonics during the Neoproterozoic assembly of Gondwana. Precambrian Research, 149: 43-63.

Alkmim, F.F., Pedrosa-Soares, A.C., Noce, C.M. \& Cruz, S.C.P. 2007. Sobre a Evolução Tectônica do Orógeno Araçuaí-Congo Ocidental. Geonomos, 15: neste número.

Aracema, L.W., Neves, A.C., Ferreira, J.C., Pedrosa-Soares, A.C., Lobato, L.M. \& Noce, C.M. 2000. Novas evidências de remanescentes oceânicos na Faixa Araçuaí: As rochas metaultramáficas de São José da Safira. Geonomos, 8 (1): 55-61.

Coleman, R.G. \& Peterman, Z.E. 1975. Oceanic plagiogranite. Journal Geophysical Research, 80: 1099-1108.

Mukasa, S.B. \& Ludden, J.N. 1987. Uranium-lead isotopic ages of plagiogranites from the Troodos Ophiolite, Cyprus, and their tectonic significance. Geology: 15: 825-828.

Pedrosa-Soares, A.C., Noce, C.M., Vidal, P., Monteiro, R. \& Leonardos, O.H. 1992. Toward a new tectonic model for the Late Proterzoic Araçuaí (SE Brazil) - West Congolian (SW Africa) Belt. Journal of South American Earth Sciences, 6: 33-47.

Pedrosa-Soares, A.C., Vidal, P., Leonardos, O.H. \& Brito-Neves, B.B. 1998. Neoproterozoic oceanic remnants in eastern Brazil: Further evidence and refutation of an exclusively ensialic evolution for the Araçuaí-West Congo orogen. Geology, 26: 519-522.

Pedrosa-Soares, A.C., Noce, C.M., Wiedemann, C.M. \& Pinto, C.P. 2001. The Araçuaí-West Congo orogen in Brazil: An overview of a confined orogen formed during Gondwanland assembly. Precambrian Research, 110: 307-323.

Pedrosa-Soares, A.C., Noce, C.M., Alkmim, F.F., Silva, L.C., Babinski, M., Cordani, U., Castañeda, C. 2007. Orógeno Araçuaí: síntese do conhecimento 30 anos após Almeida 1977. Geonomos, 15 (este número).

Pedrosa-Soares, A.C., Alkmim, F.F., Tack, L., Noce, C.M., Babinski, M., Silva, L.C., Martins-Neto, M.A. 2008. Similarities and differences between the Brazilian and African counterparts of the Neoproterozoic Araçuaí-West-Congo orogen. Geological Society, London, Special Publications, 294 (a ser lançado em início de 2008).

Queiroga, G.N., Pedrosa-Soares, A.C., Quéméneur, J. \& Castañeda, C. 2006. A unidade metassedimentar do ofiolito de Ribeirão da Folha, Orógeno Araçuaí, Minas Gerais: petrografia, geotermobarometria e calcografia. Geonomos, 14 (1): 25-35.

Suita, M.T.F., Pedrosa-Soares, A.C., Leite, C., Nilson, A.A. \& Prichard, H. 2004 Complexos Ofiolíticos do Brasil e a Metalogenia Comparada das Faixas Araçuaí e Brasília. In: E. Pereira, R. Castroviejo \& Ortiz, F. (eds), Complejos Ofiolíticos en Iberoamérica: guías de prospección para metales preciosos. Ciencia y Tecnología para el Desarrollo-CYTED, Madrid, p. 101-132. 